Columbia International Publishing

American Journal of Advanced Food Science and Technology

(2015) Vol. 3 No. 2 pp. 107-124

doi:10.7726/ajafst.2015.1008

Review

\title{
Tackling Campylobacter: a Review
}

Joana Silva ${ }^{1}$ and Paula Teixeira ${ }^{*}$

Received 26 May 2015; Returned for revision 27 October 2015; Received in revised form 1 November 2015; Accepted 1 December 2015; Published online 12 December 2015

(C) Columbia International Publishing 2015. Published at www.uscip.us

\begin{abstract}
Campylobacteriosis is a zoonosis that can be transmitted directly or indirectly between animals and humans leading to intestinal infections. Eating undercooked chicken, or ready-to-eat foods that have been in contact with raw chicken, is the most common source of the infection (20-30\%). There are currently 25 species in the Campylobacter genus; however Campylobacter jejuni and C. coli are the two principal causes of human gastroenteritis worldwide. Though death from campylobacteriosis is rare, risk of complications in risk groups is high namely in the young and elderly, and those with concurrent chronic disease and immunocompromised status. Campylobacteriosis affects the digestive system, causing diarrhoea, abdominal pain, malaise, fever, nausea and vomiting. The costs based on the incidence, prevention and control of campylobacteriosis are high with critical impacts on surveillance programmes and hence the costs and benefits must be carefully considered. Bacteriophages have been discussed worldwide as a therapeutic tool to control and prevent Campylobacter. Another promising strategy is the addition of lactic acid bacteria and/or bacteriocins in the feed to mnimise/control Campylobacter in poultry. Antibiotic treatment is a control strategy but several authors have been describing the occurrence of multidrug resistance profiles among Campylobacter strains. There is now a strong movement against the use of antibiotics in food production. In addition, several "Model Food Codes" (proper sanitation and cooking procedures) are described in order to prevent crosscontamination, which can subsequently decrease the risk of Campylobacterinfection.
\end{abstract}

Keywords: Campylobacter spp.; Biocontrol; Campylobacteriosis; Occurrence

\section{Campylobacter and Campylobacteriosis - an Overview}

Campylobacter genus typically comprises of microaerophilic spiral-shaped Gram-negative cells. Growth under aerobic and anaerobic conditions has also been reported; they require relatively high temperatures (Silva et al., 2011). Campylobacter is the organism responsible for campylobacteriosis in humans. About 200,000 human cases are reported every year and this disease is still the most frequently reported foodborne illness in the Europe Union (EU). Recently, European Food Safety

${ }^{*}$ Corresponding e-mail: pcteixeira@porto.ucp.pt

$1 \mathrm{CBQF}$ - Centro de Biotecnologia e Química Fina, Laboratório Associado, Escola Superior de Biotecnologia, Universidade Católica, Portugal. 


\section{Joana Silva and Paula Teixeira / American Journal of Advanced Food Science and Technology}

(2015) Vol. 3 No. 2 pp. 107-124

Authority (EFSA) and European Centre for Disease Prevention and Control (ECDC) reported that for the first time in five years, human cases of campylobacteriosis decreased slightly in 2012, however, it is premature to suggest that this is the beginning of a downward trend (EFSA, 2014a). Although the number of campylobacteriosis cases is high, the number of fatalities is low $0.03 \%$; EFSA, 2014a).

In 2013, the Foodborne Diseases Active Surveillance Network (FoodNet) of the Centers for Disease Control and Prevention (CDC) in the USA, estimated an incidence of 1,382 cases of campylobacteriosis per 100,000 population in the USA and 1,010 hospitalizations represented by 12 deaths; in addition, it is estimated that for every Campylobacter case reported, there are 30 cases not diagnosed (Crim et al., 2014; http://www.cdc.gov/foodnet/).

The incubation period of campylobacteriosis is typically 2 to 4 days but can range from one to 10 days (Heymann, 2008). Studies have shown that several Campylobacter spp. have the ability to attach to and invade human intestinal epithelial cells and macrophages, damage intestinal barrier integrity, secrete toxins and strategically evade host immune responses (Man, 2011). Common symptoms include diarrhoea (frequently bloody), abdominal pain, fever, and occasionally nausea and vomiting. Severe illness might occur, sometimes fatal, especially in young children, frail or elderly people, and others with weakened immune systems, including dehydration, bloodstream infection, and symptoms mimicking acute appendicitis or ulcerative colitis (Coker, 2002; Pacanowski et al., 2008). Guillain-Barré syndrome is a well-established post-infectious complication of campylobacteriosis resulting in a polyradiculoneuropathy with a variable clinical presentation (Fokke et al., 2014). The infective dose is reportedly low, with 500 organisms required to cause illness (Silva et al., 2011).

Campylobacteriosis remains largely under-reported; early and specific diagnosis is important to ensure a favorable outcome regarding this foodborne disease. Antibiotic treatment is controversial, and only has a benefit on the duration of symptoms; some simple hygienic food handling practices can prevent Campylobacter infections (Sarkar et al., 2014). The most commonly isolated agents in human infections are $C$. coli and $C$. jejuni followed by $C$. lari; these species are carried normally in the intestinal tracts of many domestic and wild animals (Silva et al., 2011; EFSA, 2014a). In fact, most human campylobacteriosis infections are due to $C$. jejuni, 90\%, with a few due to C. coli, $10 \%$ (Wilson et al., 2008). Other species of Campylobacter have been recognized as emerging human and animal pathogens e.g. C. concisus, $C$. upsaliensis and $C$. ureolyticus (Ma, 2011).

\section{Occurrence of Campylobacter}

Eating contaminated foods (e.g. undercooked chicken and foods contaminated by raw chicken), drinking contaminated water or raw (unpasteurized) milk, and having contact with animals, particularly farm animals such as cows and chickens, as well as domestic cats and dogs, are the major modes of transmission of Campylobacter spp. In addition, Campylobacter spp. can be transmitted by the fecal-oral route (CDC, 2014). 
Joana Silva and Paula Teixeira / American Journal of Advanced Food Science and Technology

(2015) Vol. 3 No. 2 pp. 107-124

\subsection{Campylobacter in food}

Campylobacter spp. are often found in contaminated food products representing a risk of zoonotic transmission to humans; consumption of contaminated, unpasteurized animal milk and milk products, undercooked poultry and contaminated drinking water is well recognized as a vehicle of infection (EFSA, 2014b; Sarkar et al., 2014). Poultry are natural and asymptomatic carriers of $C$. jejuni and $C$. coli responsible for up to $80 \%$ of the human Campylobacter infections (Wagenaar et al., 2013). According to these authors, it is estimated that in the EU, 30\% of the human infections are associated with consumption and preparation of poultry meat. Campylobacter spp. can be present in various foodstuffs including meat, raw milk and dairy products and less frequently in fish and fishery products, mussels and fresh vegetables (EFSA, 2014a).

According to Andrzejewska et al. (2015), the occurrence of Campylobacter spp. in poultry meat from Northern Poland is $41.6 \%$ with higher incidence of C. jejuni. In Estonia, the prevalence and counts of Campylobacter spp. in poultry meat at retail level was shown to be $20.8 \%$ and $3.20 \log 10$ $\mathrm{CFU} / \mathrm{g}$ (mean number of campylobacters in fresh broiler chicken meat) (Mäesaara et al., 2014). In Latvia the occurrence of Campylobacter spp. in broiler chicken production at slaughterhouse and retail level was determined and it was reported that $92.5 \%, 60.8 \%$ and $56.3 \%$ of the pooled intestine samples, the neck skin samples and of carcasses were positive for Campylobacter spp., respectively (Kovalenkoa et al., 2014). According to these authors, a seasonal variation was observed in proportions of Campylobacter positive samples, with a seasonal peak in summer months. A total of 471 duck and goose intestinal contents were analysed by Jamalia and collaborators (Jamalia et al., 2015); $39.2 \%$ of duck and $26.1 \%$ of goose samples were positive for Campylobacter spp. The isolates were mainly C. jejuni $(85.7 \%)$ and C. coli $(14.3 \%)$. Fresh or minimally processed vegetables can be contaminated before harvest or throughout handling. The survival of $C$. jejuni strains on spinach under different conditions was evaluated (Guévremont et al., 2015). Strains of this species from different animal or environmental origins were able to survive on spinach; this survival was dependent on the storage parameters and bacterial strain. According to these authors, fresh spinach with a significant contamination can represent a threat to human health.

\subsection{Campylobacter in animals}

Poultry and poultry products are considered to be the largest contributors of human Campylobacter infection, 50-70\% estimated. Poultry includes broilers, laying hens, turkeys, ducks, and ostriches (Sharon et al., 2013). Contact with contaminated poultry, livestock or household pets, especially puppies, can also cause the disease (Sarkar et al., 2014). In fact, Campylobacter spp. colonize a wide range of hosts including pets, farm animals and wild animals. Primarily, Campylobacter is found in broiler flocks (reported prevalence varies between the EU member states, but high prevalence (63.4\%) and extremely high (83.6\%) have already been reported) but also in pigs, cattle, goats, sheep and pets (EFSA, 2014a). Little information is available concerning the role of Campylobacter spp. in large game species; Campylobacter spp. strains associated with human campylobacteriosis were infrequently detected in 33 hunting estates during two hunting seasons, indicating a limited zoonotic risk in the studied area (Díaz-Sánchez et al., 2013). The 
Joana Silva and Paula Teixeira / American Journal of Advanced Food Science and Technology

(2015) Vol. 3 No. 2 pp. 107-124

presence of Campylobacter spp. was evaluated in faeces $(\mathrm{N}=574)$ and carcasses $(\mathrm{N}=585)$ sampled from red deer $(\mathrm{N}=295)$, wild boar $(\mathrm{N}=333)$ and other ungulates (fallow deer, mouflon) $(\mathrm{N}=9)$.

The prevalence of Campylobacter spp. in fresh and dried wild-bird fecal samples was estimated by Abdollahpour et al. (2015); samples were collected from 5 publicly accessible children's playgrounds in Mashhad, Iran. Seventy and a fifty percent of the faeces were positive for Campylobacter spp; the occurrence was higher in fresh faecal samples. This study emphasizes the importance of wild bird species as a reservoir for Campylobacter spp.

\section{Outbreaks of Campylobacteriosis}

Despite the high numbers of campylobacteriosis cases, outbreaks caused by this agent are uncommon compared with sporadic cases (Little et al., 2010; Taylor et al., 2013; Revez et al., 2014). The outbreaks have historically differed from sporadic cases inseasonality and contamination source. According to Taylor and his collaborators (2013), in the USA, from 1997 to 2008, 262 outbreaks were reported, with 9,135 illnesses, 159 hospitalizations, and three deaths. According to these authors, poultry and dairy products are the most common vehicles identified for outbreaks, namely 11 and $29 \%$, respectively. Historically, few foods have been recalled due to the presence of Campylobacter spp. (Table 1), whereas contaminated drinking water and unpasteurized raw milk have occasionally been recalled due to Campylobacter contamination (Taylor et al., 2013; Revez et al., 2014). During 1998-2008, CDC received reports of 13,405 foodborne disease outbreaks, eight pathogens caused 89\% of the 5,059 confirmed, single-etiology outbreaks, 2\% caused by C. jejuni (Gould et al., 2013). In the UK, from 1992 to 2009, 114 foodborne outbreaks of campylobacteriosis were reported to the Health Protection Agency; 64\% occurred in food service establishments. Poultry meat was the most commonly reported vehicle of infection (38\%) (Little et al., 2010). According to this study, since 2007, the number of outbreaks of campylobacteriosis linked to consumption of poultry liver pâté in England and Wales significantly increased (from $12 \%$ to $74 \%$ ) with a higher frequency in December.

Table 1 Several Campylobacter outbreaks reported in recent years in Europe and internationally.

\begin{tabular}{|c|c|c|c|c|}
\hline $\begin{array}{l}\text { Reported } \\
\text { Outbreak }\end{array}$ & $\begin{array}{l}\text { Suspected food } \\
\text { vehicle }\end{array}$ & Target group & $\begin{array}{l}\text { Responsible } \\
\text { agent }\end{array}$ & Local \\
\hline $\begin{array}{c}18^{\text {th }} \text { September, } \\
2014\end{array}$ & $\begin{array}{l}\text { unpasteurized } \\
\text { raw milk }\end{array}$ & $\begin{array}{l}\text { football team in } \\
\text { Wisconsin school }\end{array}$ & $\begin{array}{c}\text { Campylobacter } \\
\text { jejuni }\end{array}$ & Madison, USA \\
\hline $\begin{array}{c}\text { 15-20th January, } \\
2014\end{array}$ & oysters & $\begin{array}{c}\text { general } \\
\text { consumers }\end{array}$ & $\begin{array}{l}\text { Campylobacter } \\
\text { spp. }\end{array}$ & Oregon, USA \\
\hline 29th May, 2013 & $\begin{array}{l}\text { unpasteurized } \\
\text { raw milk }\end{array}$ & $\begin{array}{l}\text { general } \\
\text { consumers }\end{array}$ & $\begin{array}{l}\text { Campylobacter } \\
\text { spp. }\end{array}$ & $\begin{array}{c}\text { Chambersburg, } \\
\text { PA }\end{array}$ \\
\hline $6^{\text {th }}$ June, 2013 & $\begin{array}{l}\text { food from several } \\
\text { of the } 30 \text { vendors } \\
\text { at the festival }\end{array}$ & $\begin{array}{l}\text { people who } \\
\text { attended an } \\
\text { outdoor food }\end{array}$ & $\begin{array}{l}\text { Campylobacter } \\
\text { spp. }\end{array}$ & New York, USA \\
\hline
\end{tabular}


Joana Silva and Paula Teixeira / American Journal of Advanced Food Science and Technology

(2015) Vol. 3 No. 2 pp. 107-124

\begin{tabular}{|c|c|c|c|c|}
\hline $\begin{array}{l}8^{\text {th }} \text { January }-13^{\text {th }} \\
\text { February, } 2013\end{array}$ & $\begin{array}{l}\text { unpasteurized } \\
\text { raw milk }\end{array}$ & $\begin{array}{c}\text { festival } \\
\text { residents of } \\
\text { Alaska's Kenai }\end{array}$ & Campylobacter coli & $\begin{array}{l}\text { Alaska's Kenai } \\
\text { Peninsula, USA }\end{array}$ \\
\hline 14th July, 2012 & $\begin{array}{c}\text { chicken liver pâté } \\
\text { entrée }\end{array}$ & $\begin{array}{l}\text { guests from the } \\
\text { birthday party }\end{array}$ & & \\
\hline 27th January,2012 & $\begin{array}{l}\text { unpasteurized } \\
\text { raw milk }\end{array}$ & residents & $\begin{array}{l}\text { Campylobacter } \\
\text { spp. }\end{array}$ & $\begin{array}{l}\text { Maryland } \\
\text { and } \\
\text { Pennsylvania, } \\
\text { USA }\end{array}$ \\
\hline June, 2010 & $\begin{array}{l}\text { chicken liver } \\
\text { parfait }\end{array}$ & $\begin{array}{l}\text { guests at a } \\
\text { wedding } \\
\text { reception }\end{array}$ & $\begin{array}{l}\text { Campylobacter } \\
\text { spp. }\end{array}$ & United Kingdom \\
\hline 13 th May, 2010 & Municipal water & residents & $\begin{array}{l}\text { Campylobacter } \\
\text { spp. }\end{array}$ & $\begin{array}{c}\text { Saratoga Springs, } \\
\text { Utah, USA }\end{array}$ \\
\hline $\begin{array}{l}\text { March and April } \\
\quad 2009\end{array}$ & $\begin{array}{l}\text { unpasteurized } \\
\text { raw milk }\end{array}$ & $\begin{array}{c}\text { rural } \\
\text { community }\end{array}$ & $\begin{array}{c}\text { Campylobacter } \\
\text { jejuni }\end{array}$ & $\begin{array}{l}\text { Western } \\
\text { Kansas }\end{array}$ \\
\hline $26^{\text {th }}$ October,2007 & $\begin{array}{l}\text { cheese made } \\
\text { from } \\
\text { unpasteurized } \\
\text { raw milk }\end{array}$ & $\begin{array}{l}\text { clients of a } \\
\text { restaurant }\end{array}$ & $\begin{array}{l}\text { Campylobacter } \\
\text { spp. }\end{array}$ & $\begin{array}{l}\text { Forth Valley, } \\
\text { Scotland }\end{array}$ \\
\hline December, 2006 & chicken liver pâté & $\begin{array}{l}\text { clients of a } \\
\text { restaurant }\end{array}$ & $\begin{array}{l}\text { Campylobacter } \\
\text { spp. }\end{array}$ & $\begin{array}{l}\text { Forth Valley, } \\
\text { Scotland }\end{array}$ \\
\hline $\begin{array}{c}30^{\text {th }} \text { May- } 13^{\text {th }} \text { June } \\
2000\end{array}$ & waterborne & rural farms & $\begin{array}{c}\text { Campylobacter } \\
\text { jejuni }\end{array}$ & Canada \\
\hline $\begin{array}{l}\text { March } 2002 \text { and } \\
\text { March } 2003\end{array}$ & $\begin{array}{c}\text { drain } \\
\text { contaminated } \\
\text { with pigeon feces } \\
\text { on the roof and a } \\
\text { leaking }\end{array}$ & $\begin{array}{l}\text { penitentiary } \\
\text { residents and } \\
\text { staff }\end{array}$ & $\begin{array}{c}\text { Campylobacter } \\
\text { jejuni }\end{array}$ & $\begin{array}{l}\text { Washington } \\
\text { State, USA }\end{array}$ \\
\hline
\end{tabular}

Unicomb et al. (2009) studied the frequency of Campylobacter outbreaks in Australia from January 2001 to December 2006; 33 Campylobacter outbreaks were reported, affecting 457 persons. Transmission was predominantly foodborne or suspected foodborne (82\%), 30\% of the foodborne outbreaks were attributed to food prepared or eaten at institutions; $15 \%$ at aged care facilities and $11 \%$ at school camps. Poultry (chicken or duck), waterborne, unpasteurized milk and salads were associated with the reported outbreaks. According to these authors, outbreaks continue to constitute a very small proportion of notifications since improved recognition through subtyping is required.

Parry et al. (2012) reported an outbreak of campylobacteriosis associated with chicken liver pâté at a surprise birthday party; outbreaks of this kind may be greatly underestimated 
since Campylobacter isolates are not routinely subtyped and the identification of outbreaks is largely restricted to temporal or geographical associations or reliance on medical notifications identifying common events. According to (EFSA, 2014a), half of the Campylobacter outbreaks have been related with broiler meat and raw milk. In addition, from 2008 to 2012 a clear seasonal trend was observed in Europe. In 2012, 31 deaths due to campylobacteriosis were reported (in 14 member states); 20 of those deaths were in the United Kingdom. Campylobacter jejuni and C. coli were responsible for 81.1 and $6.2 \%$ of the cases, respectively.

Globally, defining the scope of a given outbreak, identifying the source of the strains and tracing the route by which the bacteria infect the humans are crucial parameters that should be considered.

\section{Antibiotic Resistance - the Need for Alternative Controls}

Historically antibiotics have been used in livestock farming both for the treatment of infections and as growth promoters. However the practice of administering growth promoters containing antimicrobials has been gradually banned in Europe (2013).

The frequent use of antibiotics in the veterinary field, has been contributing to the increased trend in the resistance of Campylobacter strains (and also in other foodborne pathogens) isolated from man and poultry, especially to fluoroquinolones and macrolides (Endtz et al., 1991; Nachamkin et al., 2002; Wieczorek and Osek, 2013). In fact, resistant and particularly multiresistant Campylobacter strains are being alarmingly spread, representing an increasing phenomenon that demands enforced interventions at multidisciplinary levels and is one of the challenges of campylobacteriosis control, worldwide (Wimalarathna et al., 2013; Carmelo et al., 2013; EFSA, 2014b). In the European Union, antimicrobial resistance is commonly detected in Campylobacter isolated from human cases as well as from food-producing animals and food (EFSA, 2014b). According to the last summary report disseminated by EFSA (2014b), a high resistance level to ampicillin, ciprofloxacin, nalidixic acid and tetracycline among Campylobacter isolates from human cases was reported by the member states, while resistance to erythromycin was low to moderate. The resistance trend for $C$. jejuni isolates was for ciprofloxacin (54.1\%) and for nalidixic acid 53.3\%. Among C. coli isolates, $69 \%$ were reported resistant to nalidixic acid and ciprofloxacin, followed by tetracyclines $49.7 \%$ and ampicillin $36.0 \%$. Concerning isolates of $C$. jejuni and $C$. coli, the levels of resistance to erythromycin is overall low and moderately high, respectively. In addition, one in six human C. coli isolates were resistant to both erythromycin and ciprofloxacin. These two antibiotics are commonly administrated for treatment of campylobacteriosis emphasizing the problem related with combined resistance (coresistance) to critically important antimicrobials (EFSA, 2014b). However, according to EFSA, coresistance to critically important antimicrobials remains low (EFSA, 2014b).

Concerning Campylobacter isolates from food samples, namely fowl, broiler meat, pigs and cattle, high to extremely high resistance to ciprofloxacin, nalidixic acid and tetracyclines and low resistance levels for erythromycin and gentamicin were recorded (EFSA, 2014b): 59.5\%, $57.9 \%$ and $47.5 \%$ of strains of $C$. jejuni isolated from meat and broilers, were resistant to ciprofloxacin, nalidixic acid and tetracycline, respectively. For $C$. coli, the percentages of strains resistant to these three antibiotics was of $82.7 \%, 81 \%$ and $57.3 \%$, respectively (EFSA, 
Joana Silva and Paula Teixeira / American Journal of Advanced Food Science and Technology

(2015) Vol. 3 No. 2 pp. 107-124

2014b). Overall, C. coli presented a higher resistance trend compared to C. jejuni, for both human and food strains. Griggs et al. (2005) reported quinolone-resistant Campylobacter strains in commercial chicken flocks that were treated with veterinary fluoroquinolone; $53 \%$ of the $C$. jejuni and $82 \%$ of $C$. coli were ciprofloxacin resistant. In addition, these authors reported that quinolone-resistant Campylobacter strains were present in the faeces of some flocks up to the point of slaughter, thereby presenting a potential public health problem. According to Hart et al. (2004), Campylobacter strains isolated from pigs are mainly ciprofloxacin-susceptible, since in Australia the application of fluoroquinolones in animal production is prohibited. A significantly higher prevalence of Campylobacter isolates resistant to ciprofloxacin was reported by Maćkiwa et al. (2012), 97.9\%. Moreover, 7.0\% of the isolates were found to be resistant to at least three unrelated antibiotics. According to Abay et al. (2014), erythromycin, amoxicillin, clavulanic acid and gentamicin are recommended for the treatment of Campylobacteriosis in humans since most of the $C$. jejuni isolated from poultry and humans in T.urkey were sensitive to these antibiotics. Wimalarathna et al. (2013) reported that $38.02 \%$ of $C$. jejuni and $C$. coli isolates were resistant to tetracycline and $22.26 \%$ to quinolones. Concerning erythromycin and chloramphenicol, low resistance levels were observed, $4.59 \%$ and $2.59 \%$, respectively.

Jamalia et al. (2015) reported that Campylobacter isolates collected from ducks and geese were resistance to ciprofloxacin, tetracycline and nalidixic acid; among those strains, $60.2 \%$ were multidrug resistant.

In Portugal, a high resistance rate was reported for quinolones ( $\mathrm{n}=196$ Campylobacter strains; $100 \%$ to nalidixic acid and $>90 \%$ to ciprofloxacin) and, in general, resistance was more common among C. coli, especially for erythromycin (40.2\% vs. 6.7\%; Duarte et al., 2014). According to these authors, most isolates (86\%) were resistant to multiple antimicrobial families.

\section{Campylobacter and Biocontrol}

\subsection{Bacteriophages}

The widespread acquisition of antimicrobial resistance among Campylobacter isolates has been a matter of concern and the elimination of antibiotics as growth promoters in livestock is being actively examined (Ganan et al., 2012). Thereby, new, natural and sustainable strategies have been reported in the literature in order to reduce the incidence of this bacterium in the food chain, especially in its main host. One particular strategy is the use of bacteriophages, viruses that can only lyse targeted bacterial cells (Loc-Carrillo et al., 2011). The specificity of phages to the target bacteria is well known; once the phage attaches to the host cell, its DNA is ejected into the cell and takes over the host's DNA replication, transcription and translation processes to produce progeny phages. On lysis of the producing cells, 'new' phages are then capable of infecting other target cells nearby. This specificity and effectiveness prevents dysbiosis which means that the normal flora is not affected (Guttman et al., 2005). According to García et al. (2008), phages can be used to combat pathogens in food at all stages of production in the classic 'farm-to-fork' continuum in the human food chain. Phages for use as therapeutic or biocontrol agents on pathogenic bacteria such as Campylobacter, must meet a few criteria namely i) they must be obligatorily lytic and therefore only capable of infecting bacterial cells and producing progeny phage without the capacity to integrate into the bacterial genome or transduce bacterial genes from one cell to 


\section{Joana Silva and Paula Teixeira / American Journal of Advanced Food Science and Technology}

(2015) Vol. 3 No. 2 pp. 107-124

another (Canchaya et al., 2003) and ii) possess physical characteristics that will facilitate their survival in the environments to which they will be applied (Loc-Carrillo et al., 2011; Carvalho et al., 2012b).

In 2005, Wagenaar et al. reported that phage therapy is a promising alternative for reducing C. jejuni colonization in broilers, either as a preventive or a therapeutic measure. According to the results obtained, these authors suggested that the phage treatment did not prevent the colonization of the caecum, but may delay it; an initial reduction of Campylobacter by 2 $\log 10 \mathrm{CFU} / \mathrm{g}$ was observed and one week after the numbers reached out at approximately $1 \log 10$ compared with the control (no phage administered to the chicks). In the study conducted by Loc Carrillo et al. (2011), chickens were treated with two Campylobacter phages, CP8 and CP34. The results varied within the tested phage and according to the dose administered to the chicken; CP8 was shown to have the higher efficacy for reducing Campylobacter in the chicken caecum $(>5$ $\log 10 \mathrm{CFU} / \mathrm{g}$ ). Later, El- Shibiny et al. (2009) reported that a single 107 or 109 PFU (plaque forming units) dose of CP220 resulted in a $2 \log 10 \mathrm{CFU} / \mathrm{g}$ reduction in Campylobacter counts that colonized chickens; after treatment, only $2 \%$ of the recovered Campylobacter displayed resistance to CP220. More recently, Carvalho et al. (2010) studied the efficacy of a phage cocktail composed of three phages for the control of poultry infected with $C$. coli and $C$. jejuni; the phage cocktail was able to reduce by approximately $2 \log 10 \mathrm{CFU} / \mathrm{g}$ the titre of both $C$. coli and $C$. jejuni in faeces of colonized chickens.

These authors also tested the administration of phages in feed to Campylobacter-infected chicks and concluded that administering phages to poultry via the food could be successful on a commercial scale (faster reduction). Campylobacter phages have been isolated from several sources namely sewage, pig and poultry manure, abattoir effluents, broiler chickens and retail poultry. After the isolating step, phages have been characterized and special attention has been given to the lytic spectrum of each phage or a given mixture of phages. Globally, the sensitivity to individual bacteriophages varies according to the strain and specie (Bigwood et al., 2008; Carvalho et al., 2009; El-Shibiny et al., 2009; Loc-Carrillo et al., 2011; Carvalho et al., 2012b; Owens et al., 2013). To date, six Campylobacter phage sequences have been published and are available in EMBL and GeneBank (Timms et al., 2010; Kropinski et al., 2011; Carvalho et al., 2012a; Hammerl et al., 2012). The development of phage-resistant mutants has already been reported as potentially a contra- indication in the application of phages [42]; however further research is still needed to answer which type of resistance is actually relevant for phage therapy and other phage applications (Loc- Carrillo et al., 2011). Phage-based products against Campylobacter are not on the market but a few companies have publically declared interest in developing such products including Intralytix, GangaGen and Micreos (Loc-Carrillo et al., 2011).

\subsection{Probiotics and bacteriocins}

Alternative practices to biocontrol Campylobacter spp. in broiler feed are currently being investigated namely probiotics (Gaggia et al., 2010) and bacteriocins (Svetoch and Stern, 2010). However limited information is available regarding their effects in poultry namely in poultry nutrition and/or microbiology (Józefiak and Sip, 2013). Bacteriocins have either bactericidal or bacteriostatic activity and are known as antimicrobials that do not disturb the 


\section{Joana Silva and Paula Teixeira / American Journal of Advanced Food Science and Technology}

(2015) Vol. 3 No. 2 pp. 107-124

global ecosystem. Lactic acid bacteria and bacteriocins are generally recognized as safe (GRAS; so far there has been no information about negative effects on animals or humans) and their industrial interest has been increasing. However two limitations are recognized: i) the spectrum of activity of most LAB bacteriocins is rather narrow and may not inhibit the variety of microorganisms found in foods; ii) less activity against Gram-negative bacteria and iii) bacteriocin resistance. Strains producing bacteriocins are commonly spread among genera of Lactobacillus, Lactococcus, Pediococcus, Carnobacterium, Enterococcus, Escherichia, Bacillus, Paenibacillus, Staphylococcus, Pseudomonas, Clostridium, and others (Svetoch and Stern, 2010). Bacteriocins are divided into 3 classes and classes I and II are the best studied and have practical application. Cole and his collaborators (Cole et al., 2006) reported that bacteriocins produced by Bacillus circulans and Paenibacillus polymyxa reduce caecal Campylobacter colonization in broiler chickens infected with $C$. jejuni. Bacteriocins, with antimicrobial activity against $C$. jejuni, were reported to be present in broiler chicken excreta (Nazef et al., 2008; Belguesmia et al., 2011).

In 2008, Stern et al. (2008) studied the effect of adding probiotic strains to chicken feed as a prophylactic probiotic treatment. These authors reported that probiotic strains were effectively reduced $C$. jejuni colonization only when very low challenge levels of $C$. jejuni were used. Two of those probiotic strains were selected, Lactobacillus salivarius NRRL B-30514 and Paenibacillus polymyxa NRRL B-30509, and further studied for efficacy in reducing C. jejuni in chickens. Purified bacteriocins/kg feed were fed therapeutically to chickens and colonization by $C$. jejuni was reduced by at least one million-fold. However, treatments with viable probiotic bacterial cultures were ineffective in reducing $C$. jejuni in chickens.

Bacteriocin treatments can reduce poultry colonization of Campylobacter from $>10^{8} \mathrm{cfu} / \mathrm{g}$ of caecal materials to non-detectable or very low levels in treated birds (Svetoch and Stern, 2010). Connerton et al. (2011) also verified that feeding broilers with bacteriocins reduced Campylobacter to non-detectable levels. According to the work reported by Messaoudi et al. (2012), L. salivarius SMXD51, previously isolated from chicken caeca, produces a component that inhibits the growth of $C$. jejuni (bacteriocin SMXD51) that has potential to reduce Campylobacter in poultry prior to processing.

\subsection{Other alternatives for the control of Campylobacter}

Natural products from plants present good alternatives to be used in foods or as therapeutic agents in order to prevent/control Campylobacter spp. (2011). These authors tested 28 edible or medicinal plant species for their bactericidal effects on the growth of $C$. jejuni and C. coli. Acacia farnesiana, Artemisia ludoviciana, Opuntia ficus-indica, and Cynara scolymus extracts were the most effective against Campylobacter; adherence and cytotoxic activity of the bacteria to host mucosal surfaces was decreased by these extracts. In fact, plants are potential candidates for the control of Campylobacter contamination in foods, the treatment of the diseases associated with this microorganism, and as feed supplements to reduce on-farm prevalence of Campylobacter (Castillo et al., 2011).

The anti-Campylobacter effect of natural phenolic compounds extracted from plants has also been described by Klančnik and his collaborators, 2012. These authors emphasized the high 
Joana Silva and Paula Teixeira / American Journal of Advanced Food Science and Technology

(2015) Vol. 3 No. 2 pp. 107-124

potential of these agents. Salaheen and his collaborators (2014) tested the effect of the bioactive components from blueberry and blackberry pomaces on $C$. jejuni growth and pathogenicity. Blackberry and blueberry pomace extracts significantly reduced the growth of $C$. jejuni by altering some of the physicochemical properties such as the cell surface hydrophobicity and auto-aggregation of this bacterial pathogen. In addition, swimming and swarming motility of $C$. jejuni were significantly reduced as well as the expression of the virulence genes and their interactions with host cultured cells.

Solis de los Santos et al. (2009) reported that therapeutic supplementation of caprylic acid in the feed can effectively decrease Campylobacter in market-aged chickens and may be a potential treatment for decreasing pathogen carriage in poultry. Recently, Arsi et al. (2014) reported the efficacy of natural plant extracts such as thymol and carvacrol against Campylobacter colonization in broiler chickens. They observed that feed supplementation with these compounds reduced Campylobacter colonization in chickens.

The utilization of natural products in the control/prevention of Campylobacter should be in agreement with what can be legally premised in animal husbandry. Vaccination of chickens against Campylobacter has also been reported, however a commercial vaccine against Campylobacter has not yet been developed (de Zoete et al., 2007; Jagusztyn- Krynicka et al., 2009; Zeng et al., 2010). Zeng et al. (2010) developed a novel vaccine against $C$. jejuni - CmeC Subunit Vaccine. According to these authors, this approach can reduce the frequency of in vivo emergence of antibiotic resistant $C$. jejuni.

\section{Preventing Campylobacter and Good Practices}

To prevent Campylobacter infections, it is important to follow basic food hygiene practices when preparing food. In fact, improving culinary and catering practices are important procedures for 2009; Zeng et al., 2010). Zeng et al. (2010) developed a novel vaccine against $C$. jejuni CmeC Subunit Vaccine reducing exposure to Campylobacter-contaminated products (Newell et al., 2011). According to these authors, from 1992 to 2009, 114 general foodborne outbreaks of campylobacteriosis were reported to the Health Protection Agency, most occurring in food service establishments (64\%). Some food handling practices that can prevent Campylobacter infections include the following:

- Cook all types of poultry products properly; all poultry should be cooked to reach a minimum internal temperature of $74^{\circ} \mathrm{C}$;

- Wash hands frequently when preparing food especially after handling raw foods from animal origin;

- Prevent cross contamination i.e. using separate cutting boards for foods of animal origin and other foods and by thoroughly cleaning all cutting boards, countertops, and utensils with soap and hot water after preparing raw food of animal origin;

- Do not drink unpasteurized milk or untreated surface water;

- Make sure that people with diarrhea, especially children, wash their hands carefully and frequently to reduce the risk of spreading the infection;

- Wash hands with soap and hot water after contact with pet faeces. 
On the other hand, to prevent Campylobacter from being transmitted to a poultry flock (primary production), biosecurity implementations are required, namely use of modern housing that is well maintained and with limited access, boot dips, and fly screens (Newell et al., 2011). These authors also reported that complimentary non-biosecurity measures are relevant to reduce the risk of flock infection such us thoroughness of cleaning and disinfecting the poultry house between flocks. Some of these measures are concerned with appropriately treated water for drinking, reducing slaughter age and discontinuing thinning (Zeng et al., 2010). According to Guerin et al. (2010), chilling, washing, defeathering, scalding and evisceration have shown a limited effect at reducing the presence of Campylobacter. Post-slaughter irradiation or cooking on an industrial scale can reduce the risk by $100 \%$. Freezing the carcasses for 2-3 weeks can reduce the risk by > 90\%, whereas freezing for 2-3 days will reduce the risk between 50 and 90\%; these results are similar to carcass decontamination using hot water, lactic acid, acidified sodium chlorite or trisodium phosphate (EFSA, 2011; Meredith et al., 2013).

\section{The Cost of Campylobacteriosis}

EFSA claims that the cost of campylobacteriosis to public health systems and to lost productivity in the EU is estimated to be around EUR 2.4 billion a year (EFSA, 2014a). In the United States, Campylobacter is reported to be the third most prevalent bacterial pathogen with an estimated annual cost of illness to be $\$ 1.7$ billion (Jensen et al., 2015). In Europe campylobacteriosis is the most common foodborne bacterial illness and estimates of the true incidence rate for Campylobacter-associated infections is 9.2 million, with a total annual cost of $€ 2.4$ billion (Meredith et al., 2013).

According to Jensen et al. (2015), using a system-wide policy approach to reduce the risk of campylobacteriosis can be more cost-effective than a policy focusing purely on farm-level interventions. In addition, according to these authors, allowing for chemical decontamination methods may enhance cost-effectiveness of intervention strategies further. Wagenaar and collaborators (2013) commented that interventions in the poultry meat production chain have not been effectively introduced and a multilevel approach should be followed, aiming at reducing the level of contamination of consumer products rather than complete absence of Campylobacter.

\section{Conclusion}

The actual incidence rate of gastroenteritis due to Campylobacter spp. is poorly known and frequently under-reported, and several approaches are being used to estimate it. Worldwide, Campylobacter is considered to be the most frequently occurring bacterial agent of gastroenteritis. In order to control/reduce this contaminant, several promising biocontrol approaches can be considered, namely the addition of LAB such as probiotics, bacteriocins and/or bacteriophages. These suggestions are in alignment with the EFSA report and should be considered as therapeutic tools to control and prevent Campylobacter. 
Joana Silva and Paula Teixeira / American Journal of Advanced Food Science and Technology

(2015) Vol. 3 No. 2 pp. 107-124

\section{Conflict of Interest}

There is no conflict of interest.

\section{References}

Abay, S., Kayman, T., Otlu, B., Hizlisoy, H., Aydin, F. \& Ertas, N. (2014). Genetic diversity and antibiotic resistance profiles of Campylobacter jejuni isolates from poultry and humans in Turkey. International Journal of Food Microbiology, 178(16), 29-38. http://dx.doi.org/10.1016/j.ijfoodmicro.2014.03.003

Abdollahpour, N., Zendehbad, B., Alipour, A. \& Khayatzadeh, J. (2015). Wild-bird feces as a source of Campylobacter jejuni infection in children's playgrounds in Iran. Food Control, 50, 378-381. http://dx.doi.org/10.1016/i.foodcont.2014.09.007

Andrzejewska, M., Szczepańska, B., Śpica, D. \& Klawe, J. J. (2015). Trends in the occurrence and characteristics of Campylobacter jejuni and Campylobacter coli isolates from poultry meat in Northern Poland. Food Control, 51, 190-194. http://dx.doi.org/10.1016/i.foodcont.2014.11.014

Arsi K., Donoghue, A. M., Venkitanarayanan, K., Kollanoor-Johny, A., Fanatico, A. C., Blore, P. J. \& Donoghue, D. J. (2014). The Efficacy of the Natural Plant Extracts, Thymol and Carvacrol against Campylobacter Colonization in Broiler Chickens. Journal of Food Safety, 34, 321-325. http://dx.doi.org/10.1111/ifs.12129

Belguesmia, Y., Madi, A., Sperandio, D., Merieau, A., Feuilloley, M., Prevost, H., Drider, D. \& Connil, N. (2011). Growing insights into the safety of bacteriocins: the case of enterocin S37.Research Microbiology, 162, 159-163. http://dx.doi.org/10.1016/j.resmic.2010.09.019

Bigwood, T., Hudson, J. A., Billington, C., Carey-Smith, G. V. \& Heinemann, J. A. (2008). Phage inactivation of foodborne pathogens on cooked and raw meat. Food Microbiology, 25(2), 400-406. http://dx.doi.org/10.1016/j.fm.2007.11.003

Canchaya, C., Fournous, G., Chibani-Chennoufi, S., Dillmann, M. L. \& Brüssow, H. (2003). Phage as agents of lateral gene transfer. Current Opinion in Microbiology, 6, 417-424. http://dx.doi.org/10.1016/S1369-5274(03)00086-9

Carmelo, G. A., Rosa Costantino, N., Bianco, A., Pileggi, C. \& Pavia, M. (2013). Prevalence and pattern of antibiotic resistance of Campylobacter spp. in poultry meat in Southern Italy. Food Control, 32(2), 715718. http://dx.doi.org/10.1016/i.foodcont.2013.02.011

Carvalho, C. M., Gannon, B. W., Halfhide, D. E., Santos, S. B., Hayes, C. M., Roe, J. M. \& Azeredo, J. (2010). The in vivo efficacy of two administration routes of a phage cocktail to reduce numbers of Campylobacter coli and Campylobacter jejuni in chickens. BMC Microbiology, 10, 232. http://dx.doi.org/10.1186/1471-2180-10-232

Carvalho, C. M., Kropinski, A. M., Lingohr, E. J., Santos, S. B., King, J. \& Azeredo, J. (2012a). The genome and proteome of a Campylobacter coli bacteriophage vB_CcoM-IBB_35 reveal unusual features Virology Journal, 9, 35 
Joana Silva and Paula Teixeira / American Journal of Advanced Food Science and Technology

(2015) Vol. 3 No. 2 pp. 107-124

http://dx.doi.org/10.1186/1743-422X-9-35

Carvalho, C. M., Santos, S. B., Kropinski, A. M., Ferreira, E. C. \& Azeredo, J. (2012b). Dr. Ipek Kurtboke (Ed.), ISBN: 978-953-51-0272-4, InTech, DOI: 10.5772/33473. Available from:

http://www.intechopen.com/books/bacteriophages/phages-as-therapeutic-tools-to-control- themajor-foodborne-pathogens-campylobacter-and-salmonella.

http://dx.doi.org/10.5772/33473

Carvalho, C., Susano, M., Fernandes, E., Santos, S., Gannon, B., Nicolau, A., Gibbs, P., Teixeira, P.\& Azeredo, J. (2009). Method for bacteriophage isolation against target Campylobacter strains. Letter of Applied Microbiology, 50, 192-197.

http://dx.doi.org/10.1111/j.1472-765X.2009.02774.x

Castillo, S. L., Heredia, N., Contreras, J. F. \& García, S. (2011). Extracts of edible and medicinal plants in inhibition of growth, adherence, and cytotoxin production of Campylobacter jejuni and Campylobacter coli. Journal of Food Science, 76, M421-426. http://dx.doi.org/10.1111/j.1750-3841.2011.02229.x

CDC (2014) Infectious diseases related to travel campylobacteriosis; http://wwwnc.cdc.gov/travel/yellowbook/2014/chapter-3-infectious-diseases-related-totravel/campylobacteriosis.

Coker, A. O., Isokpehi. R. D., Thomas, B. N., Amisu, K. O. \& Obi, C. L. (2002). Human campylobacteriosis in developing countries. Emerging Infectious Diseases, 8(3), 237-244. http://dx.doi.org/10.3201/eid0803.010233

Cole, K., Farnell, M. B., Donoghue, A. M., Stern, N. J., Svetoch, E. A., Eruslanov, B. N., Volodina, L. I.,Kovalev, Y. N., Perelygin, V. V., Mitsevich, E. V., Mitsevich, I. P., Levchuk, V. P., Pokhilenko, V. D., Borzenkov, V. N., Svetoch, O. E., Kudryavtseva, T.Y., Reyes-Herrera, I., Blore, P. J., Solis de los Santos, F. \& Donoghue, D.J. (2006). Bacteriocins reduce Campylobacter colonization and alter gut morphology in turkey poults. Poultry Science 85(9), 1570-1575. http://dx.doi.org/10.1093/ps/85.9.1570

Connerton, P. L., Timms, A. R. \& Connerton, I. F. (2011). Campylobacter bacteriophages and bacteriophage therapy. Journal of Applied Microbiology, 111(2), 255-265. http://dx.doi.org/10.1111/j.1365-2672.2011.05012.x

Crim, S. M., Iwamoto, M., Huang, J. Y., Griffin, P. M., Gilliss, D., Cronquist, A. B., Carter, M., Tobin-D'Angelo, M., Blythe, D., Smith, K., Lathrop, S., Zansky, S., Cieslak, P. R., Dunn, J., Holt, K. G., Lance, S., Tauxe, R. \& Henao, O. L. (2014). Incidence and trends of infection with pathogens transmitted commonly through food-Foodborne Diseases Active Surveillance Network, 10 U.S. sites, 2006-2013. Morbidity and Mortality Weekly Report, 63(15), 328-332.

Díaz-Sánchez, S., Sánchez, S., Herrera-León, S., Porrero, C., Blanco, J., Dahbi, G., Blanco, J. E., Mora, A., Mateo, R., Hanning, I. \& Vidal, D. (2013). Prevalence of Shiga toxin-producing Escherichia coli, Salmonella spp. and Campylobacter spp. in large game animals intended for consumption: Relationship with management practices and livestock influence. Veterinary Microbiology, 163(2), 274-281. http://dx.doi.org/10.1016/i.vetmic.2012.12.026

Duarte, A., Santos, A., Manageiro, V., Martins, A., Fraqueza, M. J., Caniça, M., Domingues, F. C. \& Oleastro, M. (2014). Human, food and animal Campylobacter spp. isolated in Portugal: high genetic diversity and antibiotic resistance rates. International Journal of Antimicrobial Agents, 44, 306-313.

http://dx.doi.org/10.1016/j.ijantimicag.2014.06.012 
Joana Silva and Paula Teixeira / American Journal of Advanced Food Science and Technology (2015) Vol. 3 No. 2 pp. 107-124

EFSA. (2011). Scientific Opinion on Campylobacter in broiler meat production: control options and performance objectives and/or targets at different stages of the food chain1 EFSA Journal, 9, 2105.

EFSA. (2014a). The European Union Summary Report on Trends and Sources of Zoonoses, Zoonotic Agents and Food-borne Outbreaks in 2012. EFSA Journal, 12 (2), 3547.

EFSA. (2014b). The European Union Summary Report on antimicrobial resistance in zoonotic and indicator bacteria from humans, animals and food in 2012. EFSA Journal, 12(3), 3590.

El-Shibiny, A., Scott. A., Timms, A., Metawea, Y., Connerton, P. \& Connerton, I. (2009). Application of a group II Campylobacter bacteriophage to reduce strains of Campylobacter jejuni and Campylobacter coli colonizing broiler chickens. Journal Food Protection, 72, 733-740.

Endtz, H. P., Ruijs, G. J., Van, Klingeren B., Jansen, W. H., Van der Reyden, T. \& Mouton, R. P. (1991). Quinolone resistance in Campylobacter isolated from man and poultry following the introduction of fluoroquinolones in veterinary medicine. Journal of Antimicrobial Chemotherapy, 27(2), 199-208. http://dx.doi.org/10.1093/jac/27.2.199

Fokke, C., van den Berg, B., Drenthen, J., Walgaard, C., van Doorn, P. A. \& Jacobs, B. C. (2014). Diagnosis of Guillain-Barré Syndrome and Validation of Brighton Criteria, Brain, 137, 33-43. Gaggìa, F., Mattarelli, P. \& Biavati, B. (2010). Probiotics and prebiotics in animal feeding for safe food production. International Journal of Food Microbiology, 141 Suppl 1, S15.

Ganan, M., Silván, J. M., Carrascosa, A. V. \& Martínez-Rodríguez, A. J. (2012). Alternative strategies to use antibiotics or chemical products for controlling Campylobacter in the food chain. Food Control, 24(1-2), 6-14.

http://dx.doi.org/10.1016/j.foodcont.2011.09.027

García, P., Martínez, B. Obeso, J. M. \& Rodríguez, A. (2008). Bacteriophages and their application in food safety. Letter of Applied Microbiology, 47, 479-485. http://dx.doi.org/10.1111/j.1472-765X.2008.02458.x

Gould, L. H., Walsh, K. A., Vieira A. R., Herman K., Williams I. T. \& Hall A. J. (2013). Surveillance for Foodborne Disease Outbreaks — United States, 1998-2008. Morbidity and Mortality Weekly Report (http://www.cdc.gov/mmwr/pdf/ss/ss6202.pdf).

Griggs, D. J., Johnson, M. M., Frost, J. A., Humphrey, T., Jørgensen, F. \& Piddock, L. J. V. (2005). Incidence and mechanism of ciprofloxacin resistance in Campylobacter spp. isolated from commercial poultry flocks in the United Kingdom before, during, and after fluoroquinolone treatment. Antimicrobial Agents and Chemotherapy, 49(2), 699-707. http://dx.doi.org/10.1128/AAC.49.2.699-707.2005

Guerin, M. T., Sir, C., Sargeant, J. M., Waddell, L., O'Connor, A. M., Wills, R. W., Bailey, R. H. \& Byrd, J. A. (2010). The change in prevalence of Campylobacter on chicken carcasses during processing: a systematic review. Poultry Science, 89, 1070-1084. http://dx.doi.org/10.3382/ps.2009-00213

Guévremont, E., Lamoureux, L., Ward, P. \& Villeneuve, S. (2015). Survival of Campylobacter jejuni on fresh spinach stored at $4{ }^{\circ} \mathrm{C}$ or $12{ }^{\circ} \mathrm{C}$. Food Control, 50, 736-739.

http://dx.doi.org/10.1016/j.foodcont.2014.10.023

Guttman, B., Raya, R. \& Kutter, E. (2005). Basic Phage Biology, In: E. Kutter and A. Sulakvelidze (Eds.), Bacteriophages: Biology and Applications, CRC Press.

Hammerl, J. A., Jackel, C., Reetz, J. \& Hertwig, S. (2012). The Complete Genome Sequence of Bacteriophage CP21 Reveals Modular Shuffling in Campylobacter Group II Phages Journal of Virology, 86, 8896. 


\section{Joana Silva and Paula Teixeira / American Journal of Advanced Food Science and Technology}

(2015) Vol. 3 No. 2 pp. 107-124

http://dx.doi.org/10.1128/JVI.01252-12

Hart, W. S., Heuzenroeder, M. W. \& Barton, M. D. (2004). Antimicrobial resistance in Campylobacter spp., Escherichia coli and enterococci associated with pigs in Australia. Journal of veterinary medicine. B, Infectious diseases and veterinary public health, 51(5), 216-221. http://dx.doi.org/10.1111/j.1439-0450.2004.00760.x

Heymann, M. D. (2008). Control of Communicable Diseases Manual 19th Edition. Washington, World Health Organization and American Public Health Association.

Jagusztyn-Krynicka, E. K., Łaniewski, P. \& Wyszyńska, A. (2009). Update on Campylobacter jejuni vaccine development for preventing human campylobacteriosis. Expert Review of Vaccines,8(5), 625-645. http://dx.doi.org/10.1586/erv.09.21

Jamalia, H., Ghaderpourb, A., Radmehrc, B., Weia, K. S. C., Chaib, L. C. \& Ismaila, S. (2015). Prevalence and antimicrobial resistance of campylobacter species isolates in ducks and geese. Food Control, 50, 328330.

http://dx.doi.org/10.1016/i.foodcont.2014.09.016

Jensen, J. D., Lawsonb, L. G. \& Lundc, M. (2015). Systemic cost-effectiveness analysis of food hazard reduction - Campylobacter in Danish broiler supply. European Journal of Operational Research, 241, 273. http://dx.doi.org/10.1016/j.ejor.2014.08.025

Józefiak, D. \& Sip, A. (2013). Bacteriocins In Poultry Nutrition - A Review. Annals of Animal Science, 13(3), 449-462. http://dx.doi.org/10.2478/aoas-2013-0031

Klančnik, A., Možina, S. S. \& Zhang, Q. (2012). Anti-Campylobacter activities and resistance mechanisms of natural phenolic compounds in Campylobacter. PLoS ONE, 7(12), e51800. doi:10.1371/journal.pone.0051800. http://dx.doi.org/10.1371/journal.pone.0051800

Kovalenkoa, K., Roastob, M., Liepinša, E., Mäesaarb, M. \& Hörmand, A. (2014). High occurrence of Campylobacter spp. in Latvian broiler chicken production. Food Control, 29, 188-191. http://dx.doi.org/10.1016/i.foodcont.2012.06.022

Kropinski, A. M., Arutyunov, D., Foss, M., Cunningham, A., Ding, W., Singh, A., Pavlov, A. R., Henry, M., Evoy, S., Kelly, J. \& Szymanski, C. M. (2011). Genome and proteome of Campylobacter jejuni bacteriophage NCTC 12673. Applied and Environmental Microbiology, 77, 8265-8271. http://dx.doi.org/10.1128/AEM.05562-11

Little, C. L., Gormley, F. J., Rawal, N. \& Richardson, J. F. (2010). A recipe for disaster: outbreaks of campylobacteriosis associated with poultry liver pâté in England and Wales. Epidemiology Infections, $138,1691-1694$. http://dx.doi.org/10.1017/S0950268810001974

Loc Carrillo, C. M., Connerton, P. L., Pearson, T. \& Connerton, I. F. (2007). Free-range layer chickens as a source of Campylobacter bacteriophage. Antonie Van Leeuwenhoek, 92, 275-284. http://dx.doi.org/10.1007/s10482-007-9156-4

Loc Carrillo, C., Atterbury, R. J., El-Shibiny, A., Connerton, P. L., Dillon, E., Scott, A. \& Connerton, I. F. (2005). Bacteriophage therapy to reduce Campylobacter jejuni colonization of broiler chickens. Applied and Environmental Microbiology, 71(11), 6554-6563. http://dx.doi.org/10.1128/AEM.71.11.6554-6563.2005 
Joana Silva and Paula Teixeira / American Journal of Advanced Food Science and Technology

(2015) Vol. 3 No. 2 pp. 107-124

Loc-Carrillo, C. \& Abedon, S. T. (2011). Pros and cons of phage therapy. Bacteriophage, 1(2), 111-114. http://dx.doi.org/10.4161/bact.1.2.14590

Maćkiwa, E., Korsaka, D., Rzewuskaa, K., Tomczuka, K. \& Rożynekc, E. (2012). Antibiotic resistance in Campylobacter jejuni and Campylobacter coli isolated from food in Poland. Food Control, 23(2), 297 301. http://dx.doi.org/10.1016/i.foodcont.2011.08.022

Mäesaara, M., Praakleb, K., Meremäea, K., Kramarenkoa, T., Sõgeld, J., Viltrope, A., Muutraa, K., Kovalenkof, K., Matta, D., Hörmang, A., Hänninenh, M. \& Roastoa, M. (2014). Prevalence and counts of Campylobacter spp. in poultry meat at retail level in Estonia. Food Control, 44, 72-77. http://dx.doi.org/10.1016/i.foodcont.2014.03.044

Man, S. M. (2011). The clinical importance of emerging Campylobacter species. Nature Reviews Gastroenterology \& Hepatology, 25(8), 669-685. http://dx.doi.org/10.1038/nrgastro.2011.191

Meredith, H., McDowell, D. \& Bolton, D. J. (2013). An evaluation of trisodium phosphate, citric acid and lactic acid cloacal wash treatments to reduce Campylobacter, TVC and TEC on broiler carcasses during processing. Food Control, 32, 149-152. http://dx.doi.org/10.1016/i.foodcont.2012.11.026

Messaoudi, S., Kergourlay, G., Dalgalarrondo, M., Choiset, Y., Ferchichi, M., Prévost, H., Pilet, M., Chobert, J., Manaic, M. \& Dousset, X. (2012). Purification and characterization of a new bacteriocin active against Campylobacter produced by Lactobacillus salivarius SMXD51. Food Microbiology, 32(1), 129-134. http://dx.doi.org/10.1016/j.fm.2012.05.002

Nachamkin, I., Ung, H. \& Li, M. (2002). Increasing fluoroquinolone resistance in Campylobacter jejuni, Pennsylvania, USA, 1982-2001. Emerging Infectious Diseases, 8(12), 1501-1503. http://dx.doi.org/10.3201/eid0812.020115

Nazef, L., Belguesmia, Y., Tani, A., Prevost, H. \& Drider, D. (2008). Identification of lactic acid bacteria from poultry feces: evidence on anti-campylobacter and anti-listeria activities. Poultry Science, 87, 329-334 http://dx.doi.org/10.3382/ps.2007-00282

Newell, D. G., Elvers, K. T., Dopfer, D., Hansson, I., Jones, P., James, S., Gittins, J., Stern, N. J., Davies, R., Connerton, I., Pearson, D., Salvat, G. \& Allen, V. M. (2011). Biosecurity-based interventions and strategies to reduce Campylobacter spp. on poultry farms. Applied and Environmental Microbiology, $77(24), 8605-8614$. http://dx.doi.org/10.1128/AEM.01090-10

Owens, J., Barton, M. D. \& Heuzenroeder, M. W. (2013). The isolation and characterization of Campylobacter jejuni bacteriophages from free range and indoor poultry. Veterinary Microbiology, 162(1), 144-150. http://dx.doi.org/10.1016/j.vetmic.2012.08.017

Pacanowski, J., Lalande, V., Lacombe, K., Boudraa, C., Lesprit, P., Legrand, P., Trystram, D., Kassis, N., Arlet, G., Mainardi, J., Doucet-Populaire, F., Girard, P., Meynard, J. \& CAMPYL Study Group. (2008).

Campylobacter bacteremia: clinical features and factors associated with fatal outcome. Clinical Infectious Diseases, 47(6), 790-796. http://dx.doi.org/10.1086/591530

Parry, A., Fearnley, E. \& Denehy, E. (2012). Outbreak of Campylobacter infection associated with chicken liver pâté at a surprise birthday party, Adelaide, Australia, 2012. Western Pacific Surveillance and Response Journal, 3(4), 16-19. 
Joana Silva and Paula Teixeira / American Journal of Advanced Food Science and Technology

(2015) Vol. 3 No. 2 pp. 107-124

http://dx.doi.org/10.5365/wpsar.2012.3.4.011

Revez, J., Llarena, A., Schott, T., Kuusi, M., Hakkinen, M., Kivistö, R., Hänninen, M. \& Rossi, M. (2014).

Genome analysis of Campylobacter jejuni strains isolated from a waterborne outbreak. BMC Genomics, 15(1),768. http://dx.doi.org/10.1186/1471-2164-15-768

Salaheen, S., Nguyen, C., Hewes, D. \& Biswasa, D. (2014). Cheap extraction of antibacterial compounds of berry pomace and their mode of action against the pathogen Campylobacter jejuni. Food Control, 46, 174-181. http://dx.doi.org/10.1016/j.foodcont.2014.05.026

Sarkar, S. R., Hossain, M. A., Paul, S. K., Ray, N. C., Sultana, S., Rahman, M. M. \& Islam, A. (2014). Campylobacteriosis - an overview. Mymensingh Medical Journal, 23(1), 173-180.

Sharon, V. R., Harvey, R. B., Hume, M. E., Phillips, T. D., Anderson, R. C. \& Nisbet, D. J. (2013). Foodborne Campylobacter: Infections, Metabolism, Pathogenesis and Reservoirs International Journal Environmental Research Public Health, 10(12), 6292-6304. http://dx.doi.org/10.3390/ijerph10126292

Silva, J., Leite, D., Fernandes, M., Mena, C., Gibbs, P. A. \& Teixeira, P. (2011). Campylobacter spp. as a Foodborne Pathogen: A Review. Frontiers in Microbiology, 2, article 200, 1-12.

Solis de los Santos, F., Donoghue, A. M., Venkitanarayanan, K., Metcalf, J. H., Reyes-Herrera, I., Dirain, M. L., Aguiar, V. F., Blore, P. J. \& Donoghue, D. J. (2009). The natural feed additive caprylic acid decreases Campylobacter jejuni colonization in market-aged broiler chickens. Poultry Science, 88, 61-64. http://dx.doi.org/10.3382/ps.2008-00228

Stern, N. J., Eruslanov, B. V., Pokhilenko, V. D., Kovalev, Y. N., Volodina L. L., Perelygin, V. V., Svetoch, E. A. (2008). Bacteriocins reduce Campylobacter jejuni colonization while bacteriproducing bacteriocins are ineffective. Microbial Ecology Health and Disease, 20, 7479.

http://dx.doi.org/10.1080/08910600802030196

Svetoch, E. A. \& Stern, N. J. (2010). Bacteriocins to control Campylobacter spp. in poultry-A review. Poultry Science, 89(8), 1763. http://dx.doi.org/10.3382/ps.2010-00659

Taylor, E. V., Herman, K. M., Ailes, E. C., Fitzgerald, C., Yoder, J. S., Mahon, B. E. \& Tauxe, R. V. (2013). Common source outbreaks of Campylobacter infection in the USA, 1997-2008. Epidemiology Infections, 141(5), 987-996. http://dx.doi.org/10.1017/S0950268812001744

Timms, A. R., Cambray-Young, J., Scott, A. E., Petty, N., Connerton, P. L., Clarke, L., Seeger, K., Quail, M., Cummings, N., Maskell, D. J., Thomson, N. R. \& Connerton, I. F. (2010). Evidence for a lineage of virulent bacteriophages that target Campylobacter. BMC Genomics, 11, 214. http://dx.doi.org/10.1186/1471-2164-11-214

Unicomb, L. E., Fullerton, K. E., Kirk, M. D. \& Stafford, R. J. (2009) Outbreaks of campylobacteriosis in Australia, 2001 to 2006. Foodborne Pathogen Diseases, 6(10), 1241-1250. http://dx.doi.org/10.1089/fpd.2009.0300

Wagenaar, J. A., French, N. P. \& Havelaar, A. H. (2013). Preventing Campylobacter at the source: why is it so difficult? Clinical Infectious Diseases, 57(11), 1600-1606. http://dx.doi.org/10.1093/cid/cit555 
Joana Silva and Paula Teixeira / American Journal of Advanced Food Science and Technology (2015) Vol. 3 No. 2 pp. 107-124

Wieczorek, K. \& Osek, J. (2013). Antimicrobial Resistance Mechanisms among Campylobacter. BioMed Research International, 340605.

http://dx.doi.org/10.1155/2013/340605 